\title{
Performance and Cost-Effectiveness of Short Pitch-Based Carbon Fiber Reinforced Mortar Composite
}

\author{
Md. Safiuddin $1,2,3, *\left(\mathbb{D}\right.$, George Abdel-Sayed ${ }^{3}$ and Nataliya Hearn $^{3}$ \\ 1 Angelo DelZotto School of Construction Management, George Brown College, 146 Kendal Avenue, \\ Toronto, ON M5T 2T9, Canada \\ 2 Department of Civil Engineering, Faculty of Engineering and Architectural Science, Ryerson University, \\ 350 Victoria Street, Toronto, ON M5B 2K3, Canada \\ 3 Department of Civil and Environmental Engineering, Faculty of Engineering, University of Windsor, \\ 401 Sunset Avenue, Windsor, ON N9B 3P4, Canada; geosayed@yahoo.com (G.A.-S.); \\ drhearn@gmail.com (N.H.) \\ * Correspondence: msafiuddin@georgebrown.ca or safiq@yahoo.com; Tel.: +1-416-415-5000 (ext. 6692)
}

Citation: Safiuddin, M.

Abdel-Sayed, G.; Hearn, N.

Performance and Cost-Effectiveness of Short Pitch-Based Carbon Fiber Reinforced Mortar Composite.

Materials 2021, 14, 4693.

https://doi.org/10.3390/ma14164693

Academic Editor: Hyeong-Ki Kim

Received: 9 July 2021

Accepted: 17 August 2021

Published: 20 August 2021

Publisher's Note: MDPI stays neutral with regard to jurisdictional claims in published maps and institutional affiliations.

Copyright: (c) 2021 by the authors. Licensee MDPI, Basel, Switzerland. This article is an open access article distributed under the terms and conditions of the Creative Commons Attribution (CC BY) license (https:// creativecommons.org/licenses/by/ $4.0 /)$.

\begin{abstract}
This paper discusses the performance of the short pitch-based carbon fiber reinforced mortar (CFRM) composite considering its key properties and cost-effectiveness. Five different types of mortar composite were produced using $0-4 \%$ volume contents of short pitch-based carbon fibers. The mortar composites were tested for inverted slump cone flow (flow time and volume flow), unit weight, air content, compressive strength, flexural strength, impact resistance, and water absorption. The cost-effectiveness of CFRM was assessed based on the performance to cost ratio (PCR), which was calculated for each mortar composite, considering its workability, mechanical properties, and durability. The inverted slump cone volume flow was counted as a measure of workability, whereas the compressive strength, flexural strength, and impact resistance were considered as the major attributes of the mechanical behavior. In addition, the water absorption was used as a measure of durability. The test results revealed that the mortar composite made with $3 \%$ carbon fibers provided adequate workability, a relatively high unit weight and low air content, the highest compressive strength, excellent flexural strength, good impact resistance, and the lowest water absorption. It was also found that the PCR increased up to $3 \%$ carbon fibers. Beyond a $3 \%$ fiber content, the PCR significantly decreased. The overall research findings revealed that the mortar with $3 \%$ carbon fibers was the optimum and most cost-effective mortar composite.
\end{abstract}

Keywords: air content; carbon fibers; compressive strength; flexural strength; impact resistance; inverted slump cone flow; mortar; performance to cost ratio; unit weight; water absorption

\section{Introduction}

Cement-based materials typically exhibit brittleness and a low tensile strength, which can be improved by incorporating fibers [1-3]. Fibers are slender and elongated filaments in the forms of bundles, networks, or strands of any natural or manufactured material that can be distributed throughout the freshly mixed cement composites [4]. They are used in cement composites to improve their tensile, flexural, and impact behaviors with simultaneous increases in stiffness, toughness, and elongation at failure [5-12]. Fibers control the propagation of cracks under loading, and thus enhance the tensile strength, flexural strength, and impact resistance of cement composites [2,13-16]. Fiber reinforced cement composite can continue to carry a considerable amount of loading after the occurrence of cracking [17]. This means that the low fracture toughness of plain cement composite is rectified significantly in the presence of fibers. Consequently, a more stable crack growth is induced before the cracks become unstable. Therefore, the cracks can also sustain a much wider opening before instability occurs [18]. In fact, the fibers act as stress-transfer bridges $[8,14]$ and thereby reduce the stress intensity at the crack tips. 
The most common fibers used in mortar and concrete are steel, glass, and polymeric fibers such as polypropylene and polyvinyl alcohol, as well as advanced fibers like aramid and carbon fibers [8-13,18]. The Japanese started the use of short carbon fibers in cement composites in a form known as carbon fiber reinforced composite (CFRC). CFRC is advantageous over polypropylene, glass, and steel fiber reinforced cement composites regarding finishability, weatherability, mixability, thermal resistance, and long-term chemical stability in aggressive environments [19]. Mostly short pitch-based carbon fibers have been used in CFRC. Pitch-based carbon fiber appeared in Japan in 1980 [20] and became prominent owing to its lower cost than other advanced fibers.

In the past, significant research was carried out to investigate the potential of pitchbased carbon fibers [16,21-29]. In particular, the mass production and industrialization of CFRCs went on in Japan in the form of curtain walls for high-rise buildings [20,21,28,29]. Carbon fibers were first used at a large scale in the form of lightweight cladding tile panels for the Al-Shaheed Monument in Iraq in 1982 [21]. After this successful application, CFRC was used structurally in the exterior curtain wall of the 37-storey Ark-Mori Building in Japan in 1986 [21]. Then, CFRCs were applied successfully in Japan to construct the curtain walls of Suidobashi Building of the Tokyo Dental College, Shinagawa-Ku Building, Hitachi Civic Center, Nihonbashi-Honcho Building, Sea Fort Square, Edo-Tokyo Museum, and the United Nations University [25,30].

The invention of pitch-based carbon fibers indeed allowed for a breakthrough in the market of advanced composite materials. Pitch-based carbon fiber was accepted as an excellent reinforcement for cementitious composites, and was used extensively for many applications, as depicted above, due to its low price compared with other advanced fibers $[19,21,25,29]$. Yet, the cost of pitch-based carbon fiber is higher than that of the other constituents of cement composites. Hence, the cost-effectiveness of CFRC should be determined before any commercial applications. However, limited studies have been conducted considering a cost analysis of CFRC in relation to its performance regarding workability, physical and mechanical properties, and durability.

The properties of fiber reinforced cement composites vary with the volume content of fibers. Shah and Rangan [31] showed that the higher volume content of fibers increased the tensile strength and toughness of the composites almost linearly. The higher fiber volume content also consistently increased the ductility and energy absorption capacity of the cement composites [32,33]. However, the higher fiber volume content was seen to significantly affect the mixing and placement of the fiber composites [18,34]. On the other hand, fiber reinforced cement composites exhibited a brittle post-peak failure pattern at a lower fiber volume content in the presence of silica fume [18]. This is because the presence of silica fume decreases the fracture toughness and makes the material more brittle $[35,36]$. Therefore, a higher fiber volume content needs to be used in the presence of silica fume. On the contrary, it is economical to keep the fiber volume content as low as possible for many fibers because of their higher price. Therefore, the optimization of the fiber content in cement composites is required. Limited studies have focused on this aspect of fiber reinforced cement composites, particularly CFRC.

This study examines the performance of the carbon fiber reinforced mortar (CFRM) composite with respect to its workability, mechanical properties, and durability. The effects of different volume contents of carbon fibers on these properties were investigated. Most importantly, a cost-performance analysis of different CFRM composites was carried out to determine the most cost-effective mortar composite.

\section{Research Significance}

CFRM composite is advantageous over conventional mortar composite due to its improved mechanical properties, particularly its flexural strength and impact resistance. However, the higher price of carbon fibers compared with other ingredients increases the material cost of the CFRM composite. The present study shows that the increased material cost of the CFRM composite can be compensated by its significantly improved 
performance. In this study, the workability (flow time and volume flow), mechanical properties (compressive and flexural strengths and impact resistance), and water absorption (a measure of durability) of different mortar composite mixes were determined. These properties are vital for a CFRM composite if it is intended for use in infrastructure (e.g., buildings, bridges, and pavements). In the present study, the effects of short pitch-based carbon fibers on the above-mentioned properties of mortar composite were investigated, and the optimum fiber content was determined based on both performance and cost. The research findings revealed that the optimum carbon fiber content was $3 \%$, which made the CFRM composite the most cost-effective by providing the highest performance to cost ratio. The maximum improvement in water absorption and compressive strength occurred for CFRM3 made with 3\% carbon fibers. Among all of the CFRMs, CFRM3 had the lowest volume of entrapped air voids and the highest unit weight. In addition, CFRM3 possessed excellent flexural strength and good impact resistance. Therefore, the optimum carbon fiber content leading to the highest performance to cost ratio of the CFRM composite was 3\%. It is expected that such an outcome from this study will guide the construction industry to produce cost-effective CFRM composite for multiple applications in infrastructure.

\section{Materials and Methods}

\subsection{Constituent Materials}

Natural river sand, ordinary Portland cement, silica fume, short pitch-based carbon fibers, normal tap water, and naphthalene-based superplasticizer were used to produce the mortar composites. The maximum particle size of the sand was $2.36 \mathrm{~mm}$. The cement conformed with the standard specification for ASTM Type I Portland cement given in ASTM C150/C150M-16 [37]. Silica fume conformed with the ASTM standard specification given in ASTM C1240-15 [38]. Short pitch-based carbon fibers were used in the form of multi-filament strands-the length and dimeter of filament was $10 \mathrm{~mm}$ and $17 \mu \mathrm{m}$, respectively. Tap water complied with the requirements, as specified in ASTM C94/C94M16 [39]. Superplasticizer conformed with the specification of Type F high-range water reducing admixture given in ASTM C494/C494M-16 [40]. The key properties of the constituent materials are given in Table 1.

Table 1. Properties of the constituent materials of the mortar composites.

\begin{tabular}{|c|c|c|}
\hline Constituent Material & Property & Value or Percentage \\
\hline \multirow{4}{*}{ River sand } & Moisture content (wt. \%) & $0.50 \%$ \\
\hline & Specific gravity $\left(\mathrm{SSD}^{*}\right)$ & 2.60 \\
\hline & Water absorption (wt. \%) & $1.60 \%$ \\
\hline & Fineness modulus & 1.97 \\
\hline \multirow{3}{*}{ Cement } & Moisture content (wt. \%) & $0.50 \%$ \\
\hline & Specific gravity & 3.15 \\
\hline & $\mathrm{pH}$ & $12-13$ \\
\hline \multirow{2}{*}{ Silica fume } & Moisture content (wt. \%) & $1.10 \%$ \\
\hline & Specific gravity & 2.20 \\
\hline \multirow{4}{*}{ Pitch-based carbon fibers } & Ultimate tensile strength & $1770 \mathrm{MPa}$ \\
\hline & Young's modulus & $180 \mathrm{GPa}$ \\
\hline & Specific gravity & 1.85 \\
\hline & $\mathrm{pH}$ & 7 \\
\hline \multirow{4}{*}{ Tap water } & Turbidity & $2.07 \mathrm{NTU}$ \\
\hline & $\mathrm{pH}$ & 7 \\
\hline & Color & $<5.00 \mathrm{TCU}$ \\
\hline & Total dissolved solids & $18 \mathrm{mg} / \mathrm{L}$ \\
\hline \multirow{3}{*}{ Naphthalene-based superplasticizer } & Specific gravity & 1.20 \\
\hline & Solid content (wt. \%) & $40 \%$ \\
\hline & $\mathrm{pH}$ & 8 \\
\hline
\end{tabular}

* Saturated surface-dry. 


\subsection{Mix Proportions of Various Mortar Composites}

In total, five different types of mortar composite mixes, including a control mix, were designed with a water-binder ratio of 0.35 and a sand-binder ratio of 0.50 . The control mix was ordinary Portland cement mortar (OPCM). Four carbon fiber reinforced mortars, namely CFRM1, CFRM2, CFRM3, and CFRM4, were designed with a fiber content of $1 \%, 2 \%, 3 \%$, and $4 \%$ by mortar volume, respectively. For all of the above mortar mixes, silica fume was considered as a $15 \%$ replacement of cement by weight. In addition, while calculating the mix proportions of the different mortar mixes based on the absolute volume method, a $1 \%$ air content was considered for OPCM, whereas a $4 \%$ air content was assumed for CFRM1. The assumed air contents were 5\%, $6 \%$, and $7 \%$ for CFRM2, CFRM3, and CFRM4, respectively.

The mix proportions for all of the mortar composite mixes were finalized based on their workability performance. A maximum inverted slump cone flow time of $30 \mathrm{~s}$ was used as the acceptability criterion for a mortar composite mix to be workable for casting specimens under vibration. This flow time was decided based on the findings from the research of Johnston [41]. The dosage of the superplasticizer by weight of the binder (cement plus silica fume) was varied to get the flow time of the mortar mixes well below $30 \mathrm{~s}$. The finalized mix proportions of the different mortar composite mixes per unit volume $\left(1 \mathrm{~m}^{3}\right)$ are shown in Table 2. Before batching, the proportions of sand and water were adjusted for each mortar mix, considering the water absorption of sand as well as the water contribution of the superplasticizer.

Table 2. Mix proportions of the different mortar composites.

\begin{tabular}{|c|c|c|c|c|c|c|}
\hline \multirow{2}{*}{$\begin{array}{c}\text { Type of Mortar } \\
\text { Mix }\end{array}$} & \multirow{2}{*}{$\begin{array}{l}\text { Binder * } \\
\left(\mathrm{kg} / \mathrm{m}^{3}\right)\end{array}$} & \multirow{2}{*}{$\begin{array}{c}\text { Sand } \\
\left(\mathrm{kg} / \mathrm{m}^{3}\right)\end{array}$} & \multicolumn{2}{|c|}{ Carbon Fibers } & \multirow{2}{*}{$\begin{array}{l}\text { Water } \\
\left(\mathrm{kg} / \mathrm{m}^{3}\right)\end{array}$} & \multirow{2}{*}{$\begin{array}{l}\text { Superplasticizer } \\
\left(\mathrm{kg} / \mathrm{m}^{3}\right)\end{array}$} \\
\hline & & & $\left(\right.$ vol. \%) ${ }^{\dagger}$ & $\left(\mathrm{kg} / \mathrm{m}^{3}\right)$ & & \\
\hline OPCM & 1124.6 & 556.2 & 0 & 0 & 394.1 & 11.3 \\
\hline CFRM1 & 1079.1 & 533.7 & 1 & 18.5 & 372.8 & 21.6 \\
\hline CFRM2 & 1056.5 & 522.4 & 2 & 37.0 & 359.8 & 31.7 \\
\hline CFRM3 & 1033.7 & 511.3 & 3 & 55.5 & 346.7 & 41.4 \\
\hline CFRM4 & 1011.1 & 500.0 & 4 & 74.0 & 334.1 & 50.6 \\
\hline
\end{tabular}

${ }^{*}$ Cement plus silica fume (15\% of binder), ${ }^{\dagger}$ Based on concrete volume.

\subsection{Preparation and Testing of Fresh Mortar Composites}

The mortar composites were prepared based on the mix proportions shown in Table 2. A pan-type mixer with a capacity of $0.1 \mathrm{~m}^{3}$ was used for preparing the fresh mortar composites. Carbon fibers were hand-sprinkled in the running mixer and mixed for $3 \mathrm{~min}$ with the other constituent materials. The total mixing time was 6 min for CFRM1, CFRM2, CFRM3, and CFRM4. In contrast, the total mixing time was 4 min for the OPCM. The details of the mix procedure are given in [42].

The freshly mixed mortars were sampled for testing the inverted slump cone flow (flow time and volume flow), unit weight, and air content. The sampling was conducted in accordance with ASTM standard practice [43].

\subsubsection{Inverted Slump Cone Test}

The inverted slump cone test was conducted according to ASTM C995 [44], with some exceptions for the shape of the container housing the cone and the filling of the cone with highly fluid OPCM. In the present study, a square wooden container was used to ease the insertion of a metal plate just below the lower end of the inverted slump cone. In addition, no vibrator was used in the case of OPCM while measuring its flow time because this mortar mix was self-flowing. 


\subsubsection{Unit Weight and Air Content Test}

The unit weight and air content of the freshly mixed mortar composites were determined according to the test procedures given in ASTM C138/C138M [45], with some exceptions for OPCM. In the case of OPCM, the cylindrical measure was filled in one layer without any vibration, as this mortar mix was self-compacting.

\subsection{Preparation and Testing of Hardened Mortar Composites}

The freshly mixed mortar mixes were used to prepare the test specimens for determining the mechanical properties of the mortar composites. For the flexure test, the beam specimens with dimensions of $400 \mathrm{~mm}$ (length) $\times 100 \mathrm{~mm}$ (height) $\times 75 \mathrm{~mm}$ (width) were cast in reusable metal molds. The $\varnothing 100 \mathrm{~mm} \times 200 \mathrm{~mm}$ cylinder specimens for the compression test were fabricated using single-use plastic molds. For the impact test, the $\varnothing 150 \mathrm{~mm}$ $\times 62.5 \mathrm{~mm}$ cylinder specimens were obtained by cutting the $\varnothing 150 \mathrm{~mm} \times 300 \mathrm{~mm}$ cylinders cast in reusable metal molds. On the other hand, the $50 \mathrm{~mm} \times 50 \mathrm{~mm} \times 50 \mathrm{~mm}$ cubes for the water absorption test were processed from the $150 \mathrm{~mm} \times 150 \mathrm{~mm} \times 150 \mathrm{~mm}$ cubes, which were also cast in reusable metal molds. ASTM standard practice [46] was followed for molding the test specimens in the laboratory. In the cases of the four CFRMs, the mortar mix was compacted by vibration while casting the test specimens. In contrast, no vibration was used for the test specimens made of OPCM.

The test specimens were de-molded after $24 \mathrm{~h}$. The bug holes, if any, were filled by neat cement paste. Then, the specimens were marked and transferred to the water tank for curing. The specimens were water-cured until the time of testing at 28 days. The curing temperature was $23 \pm 2{ }^{\circ} \mathrm{C}$. ASTM standard practice [46] was followed when curing the specimens, except for using lime in the water.

\subsubsection{Compression Test}

The compressive strength of the mortar composites at 28 days was determined according to ASTM C39/C39M [47]. Three $\varnothing 100 \mathrm{~mm} \times 200 \mathrm{~mm}$ cylinder specimens were used in this test. Before testing, they were capped with sulfur mortar following the standard practice given in ASTM C617/C617M-15 [48]. During testing, the ultimate load was recorded from the dial gauge of the compression testing machine and was used to calculate the compressive strength of the mortar composite. The average compressive strength was determined based on the test results of the triplicate $\varnothing 100 \mathrm{~mm} \times 200 \mathrm{~mm}$ cylinder specimens.

\subsubsection{Flexure Test}

The flexural strength of the mortar composites at 28 days was determined according to ASTM C 1018-97 [49]. Three $400 \mathrm{~mm}$ (length) $\times 100 \mathrm{~mm}$ (height) $\times 75 \mathrm{~mm}$ (width) beam specimens were used in this test. The loading was applied continuously without any shock by means of a hydraulic jack. The loading arrangement was connected to the data acquisition system. The ultimate load was found from the gathered data and was used to calculate the flexural strength of the mortar composite. The average flexural strength was determined from the test results of the triplicate $400 \mathrm{~mm}$ (length) $\times 100 \mathrm{~mm}$ (height) $\times$ $75 \mathrm{~mm}$ (width) beam specimens.

\subsubsection{Impact Test}

The impact resistance of the mortar composites at 28 days was determined in accordance with the test method recommended by ACI Committee 544 [50]. The amount of impact energy required to cause an opening of the cracks until failure was determined using this test method. The test set-up consisted of a standard $4.5 \mathrm{~kg}(10 \mathrm{lb})$ compaction hammer with a $457 \mathrm{~mm}$ (18 in) drop conforming with the ASTM specification for compacting hammer for use in a laboratory [51], a $63.5 \mathrm{~mm}$ (2.5 in) diameter steel ball, and a steel positioning fixture to hold the cylinder specimen. The test was performed using triplicate $\varnothing 150 \mathrm{~mm} \times 62.5 \mathrm{~mm}$ cylinder specimens, which were prepared by cutting a $\varnothing 150 \mathrm{~mm} \times$ 
$300 \mathrm{~mm}$ cylinder. The impact test was conducted by dropping the hammer repeatedly on the steel ball supported by the specimen, while observing the formation of the cracks and failure of the specimen. The number of blows required for the failure of the specimen was determined and used to compute the impact resistance. The average impact resistance was obtained from the test results of the triplicate $\varnothing 150 \mathrm{~mm} \times 62.5 \mathrm{~mm}$ cylinder specimens.

\subsubsection{Water Absorption Test}

The water absorption of the mortar composites at 28 days was determined according to the cold-water method, as specified in ASTM C1195-03 [52]. Three $50 \mathrm{~mm} \times 50 \mathrm{~mm}$ $\times 50 \mathrm{~mm}$ cube specimens were used in this test. The amount of water absorbed over a period of $48 \mathrm{~h}$ was measured so as to calculate the water absorption of each cube specimen. The average water absorption was determined from the test results of the triplicate cube specimens.

\subsection{Calculation of Cost-Effectiveness of CFRM}

Carbon fibers are costlier than any other material components of CFRM. Therefore, the cost-performance optimization of the CFRM mix is desirable to make it cost-effective. The performance and cost of CFRM were taken into consideration to evaluate its costeffectiveness. The idea introduced by Nehdi et al. [53] was used to examine the costeffectiveness of CFRMs and to obtain an optimal mix, considering their performance with respect to workability, mechanical properties, and durability. The volume flow as a measure of workability, the compressive strength, flexural strength, and impact resistance as the measures of mechanical performance, and the water absorption as a measure of durability of the mortar composites were taken into consideration to determine the cost-effectiveness in relation to the overall performance. As a basis for comparison between CFRMs and OPCM regarding the performance and cost-effectiveness, a parameter called performance to cost ratio (PCR) was determined for each mortar using the following equation.

$$
P C R=\frac{V_{f f}+\left(C_{s f} \times F_{s f} \times I_{r f} \times W_{a r f}\right)}{C_{f}}
$$

where,

$C_{f}=$ Cost factor

$V_{f f}=$ Volume flow factor

$C_{s f}=$ Compressive strength factor

$F_{s f}=$ Flexural strength factor

$I_{r f}=$ Impact resistance factor

$W_{\text {arf }}=$ Water absorption resistance factor

The values of $C_{f}, V_{f f}, C_{s f}, F_{s f}, I_{r f}$, and $W_{a r f}$ for the CFRMs can be determined after dividing their unit cost, volume flow, compressive strength, flexural strength, impact resistance, and water absorption by the corresponding unit cost and property of OPCM. Considering this computation process, Equation (1) can be modified as follows:

$$
P C R=\frac{V_{f m} / V_{f c}+\left(C_{s m} / C_{s c} \times F_{s m} / F_{s c} \times I_{r m} / I_{r c} \times W_{a c} / W_{a m}\right)}{C_{m} / C_{c}}
$$

where,

$C_{c}=$ Cost of $1 \mathrm{~m}^{3}$ of the control mortar

$C_{m}=$ Cost of $1 \mathrm{~m}^{3}$ of any mortar

$V_{f_{c}}=$ Volume flow factor of the control mortar

$V_{f m}=$ Volume flow factor of any mortar

$C_{s c}=28$-day compressive strength of the control mortar

$C_{s m}=28$-day compressive strength of any mortar 
$F_{S C}=28$-day flexural strength of the control mortar

$F_{s m}=28$-day flexural strength of any mortar

$I_{r c}=28$-day impact resistance of the control mortar

$I_{r m}=28$-day impact resistance of any mortar

$W_{a c}=28$-day water absorption of the control mortar

$W_{a m}=28$-day water absorption of any mortar

The PCRs were determined for all of the mortar composites using Equation (2), and their cost-effectiveness was evaluated from the obtained PCRs. The higher the PCR, the more cost-effective the mortar with respect to its workability, mechanical properties, and durability. Eventually, the optimum mix was defined based on the properties and PCRs of various CFRMs.

\section{Test Results and Discussion}

\subsection{Properties of Fresh Mortar Composites}

The properties of the different freshly mixed mortar composites are shown in Table 3. The flow time and volume flow of the freshly mixed mortar composites were examined to measure their workability. The flow time was recorded directly during the inverted slump cone flow test, whereas the volume flow was calculated based on the volume of mortar composite in the inverted slump cone and its flow time. The air content of each mortar composite was determined from the same test used for measuring its unit weight.

Table 3. Properties of the different freshly mixed mortar composites.

\begin{tabular}{|c|c|c|c|c|}
\hline \multirow{2}{*}{ Type of Mortar Mix } & \multicolumn{2}{|c|}{ Inverted Slump Cone Flow } & \multirow{2}{*}{ Unit Weight $\left(\mathrm{kg} / \mathrm{m}^{3}\right)$} & \multirow{2}{*}{ Air Content (\%) } \\
\hline & Volume Flow (L/s) & Flow Time (s) & & \\
\hline OPCM & 1.4 & 4 & 2070 & 1.0 \\
\hline CFRM1 & 1.0 & 5.5 & 1970 & 5.2 \\
\hline CFRM2 & 0.8 & 7 & 1945 & 6.4 \\
\hline CFRM3 & 0.6 & 8.5 & 1990 & 4.2 \\
\hline CFRM4 & 0.4 & 16.5 & 1905 & 7.9 \\
\hline
\end{tabular}

\subsubsection{Inverted Slump Cone Flow}

The flow time of mortar composite increased with the increase in the carbon fiber volume content (refer to Table 3). Therefore, the volume flow of CFRM deceased significantly as the fiber content increased. This implies that the workability of CFRM declined substantially with the increased amount of carbon fibers. Similar trends were observed by Park et al. [16], Akihama et al. [20], Bayasi and Soroushian [54], and Banthia et al. [55]. In this study, the flow time varied from $4 \mathrm{~s}$ to $16.5 \mathrm{~s}$. Generally, a flow time in the range of 8-30 s infers that the fresh composite is appropriate for casting with vibration [41]. Thus, the mortar composites including 1-4\% carbon fibers possessed sufficient workability for placing in molds or forms to make hardened elements.

The overall inverted slump cone flow results (see Table 3) show that the higher carbon fiber volume content increased the flow time, thus indicating a lower workability of the CFRM composite. CFRM4, which included $4 \%$ carbon fibers, had a lower workability compared with CFRM1 and CFRM2, which had $1 \%$ and $2 \%$ carbon fibers, respectively. This is because the higher surface area of the carbon fibers tends to restrain the mobility of the fresh mortar composite $[42,56]$ due to increased water demand to entirely wet the constituent materials. Therefore, a comparatively high superplasticizer dosage was required to make CFRM4 workable. CFRM1 (1\% carbon fibers) and CFRM2 ( $2 \%$ carbon fibers) required a $2 \%$ and $3 \%$ superplasticizer dosage, respectively. In comparison, CFRM3 (3\% carbon fibers) and CFRM4 (4\% carbon fibers) needed a $4 \%$ and $5 \%$ superplasticizer dosage, respectively. In this context, it should be mentioned that there was no visible fiber distribution problem and no fiber balling appeared during the mixing process when the mortar composite mixes were produced using the selected superplasticizer dosages. 


\subsubsection{Unit Weight and Air Content}

The unit weight of CFRM decreased in the presence of carbon fibers, as is obvious from Table 3. Park et al. [16] and Akihama et al. [20] obtained similar results from their studies. The decline in the unit weight of the CFRM composite occurred due to lightweight carbon fibers and increased air content. Among all of the solid constituents of CFRM, short pitch-based carbon fibers had the lowest specific gravity (refer to Table 1). In addition, the incorporation of carbon fibers increased the volume of entrapped air voids in the mortar composite by decreasing its workability. These two factors mainly contributed to decrease the unit weight of the CFRM composite. However, the decrease in unit weight was the lowest for CFRM3, which included 3\% carbon fibers. This is because CFRM3 had the lowest air content among all of the CFRMs (refer to Table 3). This indicates that the constituent materials became well-packed in CFRM3 when it was compacted under vibration, as compared with the other CFRMs.

The air content of the CFRM composites was significantly higher than that of OPCM. Furthermore, the air content increased to a greater extent with the higher volume content of carbon fibers, as evident from Table 3. This is because the presence of carbon fibers in the mortar impedes the movement of air voids to the surface during casting and compaction, thus entrapping them in the fresh composite [18,42]. However, it is evident from Table 3 that CFRM3 had the lowest air content. It implies that relatively less air voids were entrapped in the CFRM composite when 3\% carbon fibers were used. This is for the same reason as explained above in the case of unit weight.

\subsection{Properties of Hardened Mortar Composites}

The hardened mortar composites were tested for their compressive strength, flexural strength, impact resistance, and water absorption at 28 days. The average results of the different mortar composites obtained from the triplicate specimens are given in Table 4 .

Table 4. Properties of the different hardened mortar composites.

\begin{tabular}{ccccc}
\hline Type of Mortar Mix & $\begin{array}{c}\text { Compressive Strength } \\
\text { (MPa) }\end{array}$ & $\begin{array}{c}\text { Flexural Strength } \\
\text { (MPa) }\end{array}$ & Impact Resistance (J) & Water Absorption (wt. \%) \\
\hline OPCM & 39.0 & 5.8 & 94.1 & 13.8 \\
CFRM1 & 49.8 & 8.0 & 645.6 & 13.5 \\
CFRM2 & 56.7 & 9.0 & 961.6 & 12.7 \\
CFRM3 & 63.0 & 9.9 & 1378.6 & 11.2 \\
CFRM4 & 47.7 & 10.4 & 2810.9 & 15.6 \\
\hline
\end{tabular}

\subsubsection{Compressive Strength}

The average 28-day compressive strength results of the water cured mortar composites are presented in Table 4 . The influence of different volume contents of the carbon fibers on the compressive strength of CFRM is graphically shown in Figure 1. The standard error associated with the compressive strength results is also given in this figure. It is obvious from Figure 1 that the compressive strength of the CFRM composite increased with the inclusion of fibers for up to a $3 \%$ volume content, and then decreased sharply. Ohama et al. [29] observed a similar effect of the carbon fiber volume content on the compressive strength of cement composites. The compressive strength also dropped in their study beyond the $3 \%$ fiber content. However, it should be mentioned that they produced carbon fiber reinforced cement paste, not mortar.

The influence of the fiber content is not always beneficial for the compressive strength of the CFRM composite $[57,58]$. It greatly depends on the workability, air content, and extent of compaction of the mortar composite $[18,56]$. Although the fibers increase the compressive strength, it is rather low. This is because the fibers cannot provide a good reinforcement in compression compared with their superior reinforcing effect under tension. It is evident from Table 4 that the maximum increase in compressive strength (61\%) after 
28 days occurred for CFRM3 made with 3\% carbon fibers. Similar findings were reported by several other researchers who observed that carbon fibers could enhance the compressive strength of cement composites [59-62]. The unit weight and air content results of CFRM3 (refer to Table 3) support its maximum increase in compressive strength obtained in the present study. The increase in unit weight and the decrease in air content usually improve the compressive strength of the mortar composite [56]. CFRM3 including $3 \%$ carbon fibers possessed a comparatively high unit weight but low air content. Furthermore, the carbon fibers increase the interfacial bond strength in the composite material $[60,63]$. This is due to their inherent surface roughness. In addition, the attachment of finer cement and silica fume particles onto the carbon fibers enhances their surface roughness [18]. In the present study, the workability of CFRM3 was relatively good, as indicated by its flow time of $8.5 \mathrm{~s}$, which is much lower than the maximum acceptable limit of $30 \mathrm{~s}$. Therefore, CFRM3 was compacted well under vibration, which is evident from its unit weight and air content results. In such conditions, the interfacial bond strength can also be increased. As a result, CFRM3 provided the highest compressive strength. On the contrary, CFRM4 made with $4 \%$ carbon fibers had the lowest compressive strength among the four CFRMs (refer to Table 4). The main reason is that it was not well-compacted because of its relatively low workability. Therefore, an excessive amount of air bubbles remained entrapped in the mix, which had a negative impact on the compressive strength of CFRM4. Thus, carbon fibers can improve the compressive strength of the mortar composite if used at a volume content without affecting the workability of the mortar mix. In addition, the decrease in compressive strength could be due to the retarding effect of the excessive superplasticizer, as observed by Pigeon et al. [64]. As a relatively high dosage of superplasticizer was used in CFRM4, it might retard the setting of cement, and thus could have a negative impact on its compressive strength. Such a retarding effect is not expected for the carbon fibers at any volume content, because they are a chemically inert material and therefore are not anticipated to interfere with the hydration reactions of the binder materials.

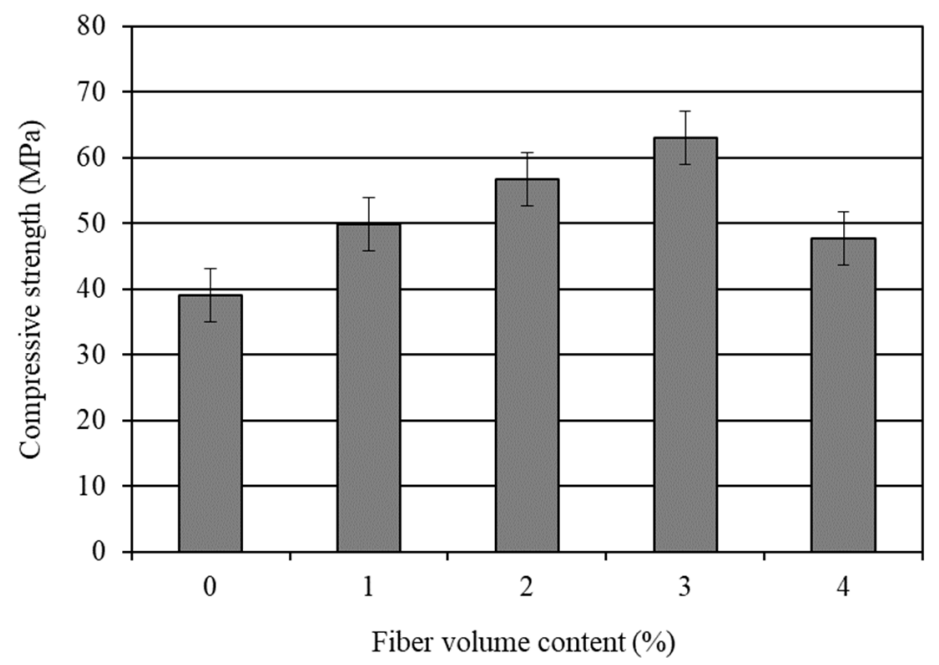

Figure 1. Influence of carbon fibers on the 28-day compressive strength of mortar composite.

\subsubsection{Flexural Strength}

The average 28-day flexural strength results of the various mortar composites are shown in Table 4. The effect of the carbon fiber content on the flexural strength of the mortar composite is graphically presented in Figure 2. The standard error associated with the flexural strength results is also shown in this figure. It is obvious from Figure 2 that the flexural strength of the CFRM composite increased with the increase in the carbon fiber content. Akihama et al. [20], Banthia and Sheng [23], and Kim and Park [65] observed a similar trend for the flexural strength of CFRC. 


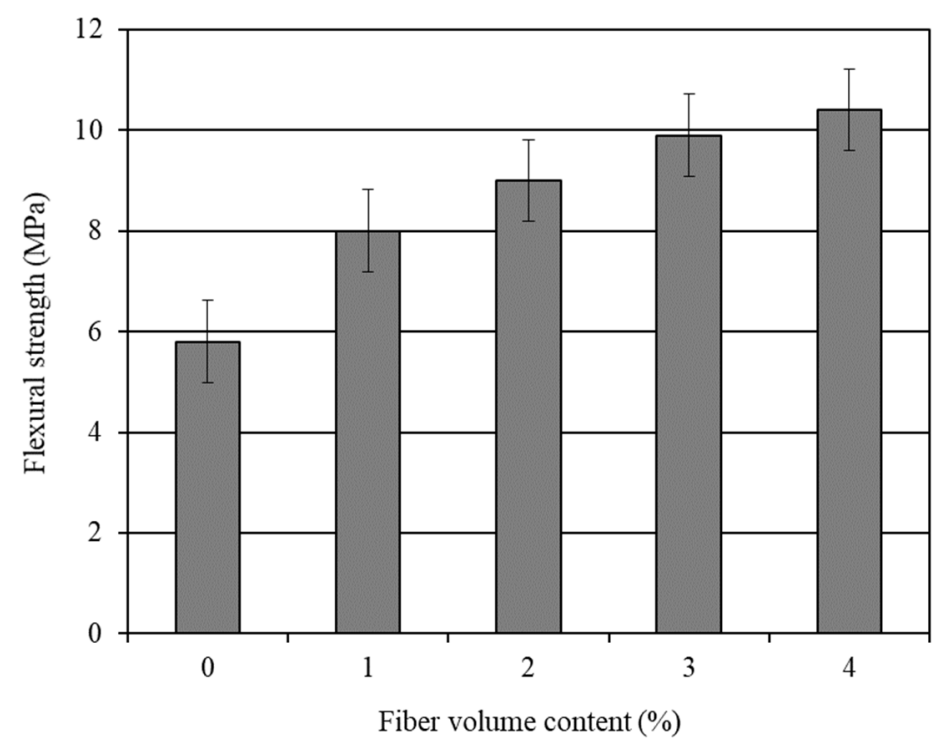

Figure 2. Influence of carbon fibers on the 28-day flexural strength of mortar composite.

The incorporation of carbon fibers significantly increased the flexural strength of the mortar composite. The mortar containing a carbon fiber volume content of $4 \%$ (CFRM4) provided the maximum flexural strength. It provided $78 \%$ more flexural strength than OPCM. On the other hand, the mortar with 3\% carbon fibers offered $70 \%$ more flexural strength than OPCM. The increase in flexural strength with the inclusion of carbon fibers is primarily because of their better reinforcing and bonding effects, resulting from the improved densification of the microstructure in the presence of silica fume and a superplasticizer [18,56]. Moreover, the orientation of the carbon fibers in the beam specimens was conducive to increase the flexural strength of the mortar composite. Sakai et al. [66] stated that carbon fibers are likely to be oriented at a right angle to the oscillating waves of a vibrator. This indicates that the compaction by a vibrator caused a $2 \mathrm{D}$ fiber orientation parallel to the axis of the beam specimens, which were used in the flexure test. Therefore, the fibers seemingly became oriented along the direction of the major tensile stress and thereby contributed to the greater flexural strength.

\subsubsection{Impact Resistance}

The average 28-day impact resistance of the different water cured mortar composites is shown in Table 4. The effect of the carbon fiber volume content is graphically presented in Figure 3. The standard error associated with the impact resistance results is also shown in this figure. It is obvious from Figure 3 that the impact resistance increased markedly with the increased carbon fiber content. The mortar composite with $4 \%$ carbon fibers (CFRM4) offered a maximum impact resistance. The impact resistance of CFRM4 was 29.86 times that of OPCM. On the other hand, the impact resistance of the mortar composite with 3\% carbon fibers (CFRM3) was 14.64 times that of OPCM. Limited studies have been conducted to examine the impact resistance of the CFRM composite using the ACI drop-weight test. Ohama et al. [29] investigated the impact resistance of CFRC operating a similar device and obtained comparable results. In addition, Soroushian et al. [10] carried out the ACI drop-weight test on a CFRC containing lightweight aggregates and observed an enormous enhancement in the impact resistance with the increased fiber content, similar to the improvement obtained in the present study. The superior improvement in the impact resistance of CFRM composite is chiefly attributed to the increased anchorage of the carbon fibers and the enhanced interfacial bond between fibers and matrix in the presence of silica fume. 


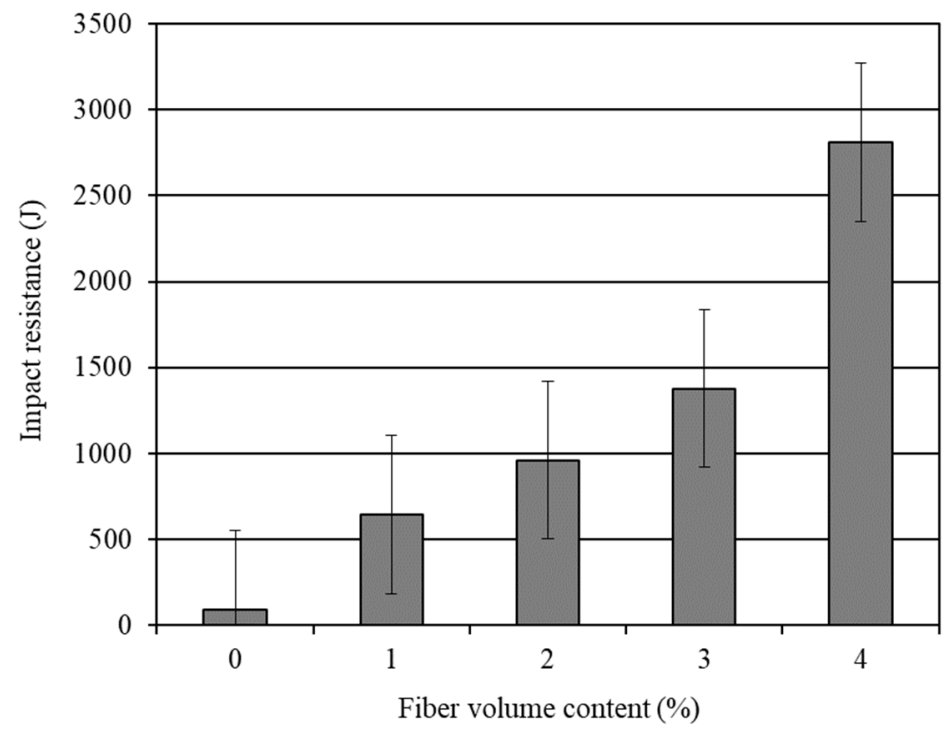

Figure 3. Influence of carbon fibers on the 28-day impact resistance of mortar composite.

\subsubsection{Water Absorption}

The average 28-day water absorption results of the various mortar composites are shown in Table 4 . The influence of the carbon fiber volume content on the water absorption is graphically presented in Figure 4. The standard error associated with the water absorption results is also shown in this figure. It is obvious from Figure 4 that the water absorption decreased up to a $3 \%$ volume content of the carbon fibers, and then increased with the $4 \%$ fiber content. Limited studies were conducted to assess the water absorption of the CFRM composite. Ohama et al. [29] executed the water absorption test on CFRC and found that the water absorption decreased with the increase in the carbon fiber volume content up to $5 \%$. A similar trend of reduction in water absorption was observed in this study for the carbon fiber volume content varying in the range of $1-3 \%$.

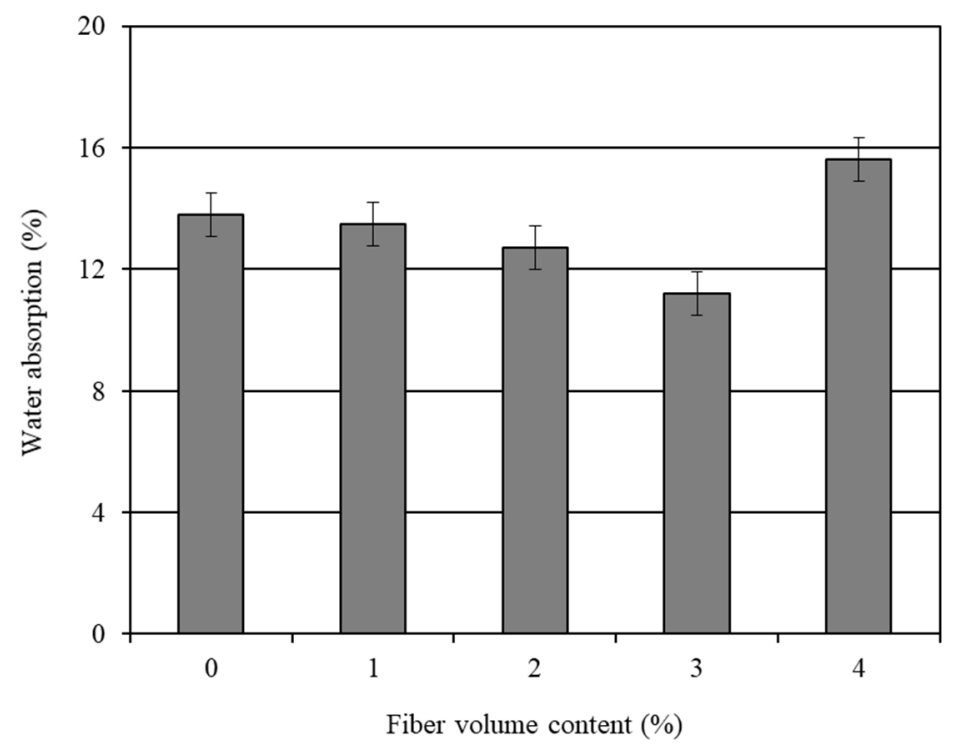

Figure 4. Influence of carbon fibers on the 28-day water absorption of mortar composite.

The mortar composite CFRM3, which included 3\% carbon fibers, had a 18.62\% lower water absorption than OPCM. In comparison, the mortar composite CFRM4, made with $4 \%$ carbon fibers, had a $12.75 \%$ higher water absorption than OPCM. This is due to the increased capillary pores and air voids of CFRM4, as understood from its unit weight and air content results. Particularly, the capillary porosity largely influenced the water 
absorption property of CFRM4. The higher the capillary porosity, the greater the water absorption [56,67]. The unit weight and air content results of CFRM3 indicate that it was well-compacted due to its sufficient workability at an adequate dosage of superplasticizer. Therefore, it is likely that CFRM3 had a lower capillary porosity. In addition, the volume of entrapped air voids was relatively low in this mortar composite. As a result, CFRM3 exhibited the lowest water absorption.

The use of a superplasticizer and silica fume was conducive to decrease the water absorption of the CFRM composite through reduced porosity. A superplasticizer allows for a substantial reduction in the amount of mix water and thereby decreases the capillary porosity of the mortar composite $[18,56]$. Moreover, silica fume contributes to decreasing the capillary porosity of cement composites [68,69] through its micro-filling ability and pozzolanic activity. In addition, it improves the interfaces of sand particles and carbon fibers [70,71] due to pore filling. However, all these improvements greatly depend on the workability of CFRM. A high workability enhances the degree of compaction and thus plays an important role in reducing the capillary pores and entrapped air voids in a mortar composite [18,42]. Excessive capillary pores were likely to exist in CFRM4 because it was too stiff due to its low workability, despite using a relatively high dosage of superplasticizer and the same amount (15\%) of silica fume. Moreover, this mortar composite contained the highest amount of entrapped air voids (refer to Table 3) because it had the lowest workability. Therefore, CFRM4 had the maximum water absorption.

\section{Cost-Effectiveness of CFRM}

The cost-effectiveness of CFRM was assessed based on the PCRs (performance to cost ratios) of different mortar composites. The PCRs were calculated based on Equation (2) comparing the performance of mortar composites with respect to the workability, mechanical behavior, and durability per unit cost. The volume flow was used as a measure of workability, whereas the compressive strength, flexural strength, and impact resistance were used to assess the mechanical behavior. Furthermore, the water absorption was used as a measure of durability. The unit cost was determined from the recent prices of the constituent materials of the mortar composites. They were gathered from the manufacturers and suppliers, except for the water. The price of tap water was obtained from the city's water rates. The summary of calculations for the PCRs of different CFRMs is given in Table 5.

Table 5. PCRs of the different mortar composites.

\begin{tabular}{|c|c|c|c|c|c|c|c|}
\hline $\begin{array}{c}\text { Type of Mortar } \\
\text { Mix }\end{array}$ & $\begin{array}{l}\text { Volume Flow } \\
\text { Factor } \\
\left(V_{f f}=V_{f m} / V_{f c}\right)\end{array}$ & $\begin{array}{l}\text { Compressive } \\
\text { Strength Factor } \\
\left(C_{s f}=C_{s m} / C_{s c}\right)\end{array}$ & $\begin{array}{c}\text { Flexural } \\
\text { Strength Factor } \\
\left(F_{s f}=F_{s m} / F_{s c}\right)\end{array}$ & $\begin{array}{c}\text { Impact Resistance } \\
\text { Factor } \\
\left(I_{r f}=I_{r m} / I_{r c}\right)\end{array}$ & $\begin{array}{l}\text { Water Absorption } \\
\text { Resistance Factor } \\
\left(W_{a r f}=W_{a m} / W_{a c}\right)\end{array}$ & $\begin{array}{l}\text { Cost Factor } \\
\left(C_{f}=C_{m} / C_{c}\right)\end{array}$ & PCR \\
\hline OPCM & 1 & 1 & 1 & 1 & 1 & 1 & 2 \\
\hline CFRM1 & 0.7143 & 1.2769 & 1.3793 & 6.8608 & 1.0222 & 2.7020 & 4.8 \\
\hline CFRM2 & 0.5714 & 1.4538 & 1.5517 & 10.2189 & 1.0866 & 4.4222 & 5.8 \\
\hline CFRM3 & 0.4286 & 1.6154 & 1.7069 & 14.6504 & 1.2321 & 6.1403 & 8.2 \\
\hline CFRM4 & 0.2857 & 1.2231 & 1.7931 & 29.8714 & 0.8846 & 7.8567 & 7.4 \\
\hline
\end{tabular}

The effect of the carbon fiber volume content on the PCR of CFRM is graphically presented in Figure 5. It can be seen from Figure 5 that the PCR increased for the CFRM composites, which included up to a 3\% carbon fiber volume content. Beyond the $3 \%$ carbon fiber content, the PCR of CFRM started to drop. The PCR of CFRM3 (the mortar composite with $3 \%$ carbon fibers) was slightly more than four times the PCR of OPCM (the mortar with $0 \%$ carbon fibers).

The workability, strength, impact resistance, and durability properties are extremely vital for any cement composite if it is intended to provide a high performance during its service life. At the same time, the cost of the cement composite is equally important. The optimum benefits are always desirable at a reasonable cost. In the context of the present study, CFRM3, which included 3\% carbon fibers, offered the highest PCR (see Figure 5), and therefore is proven to be the most cost-effective mortar composite. 


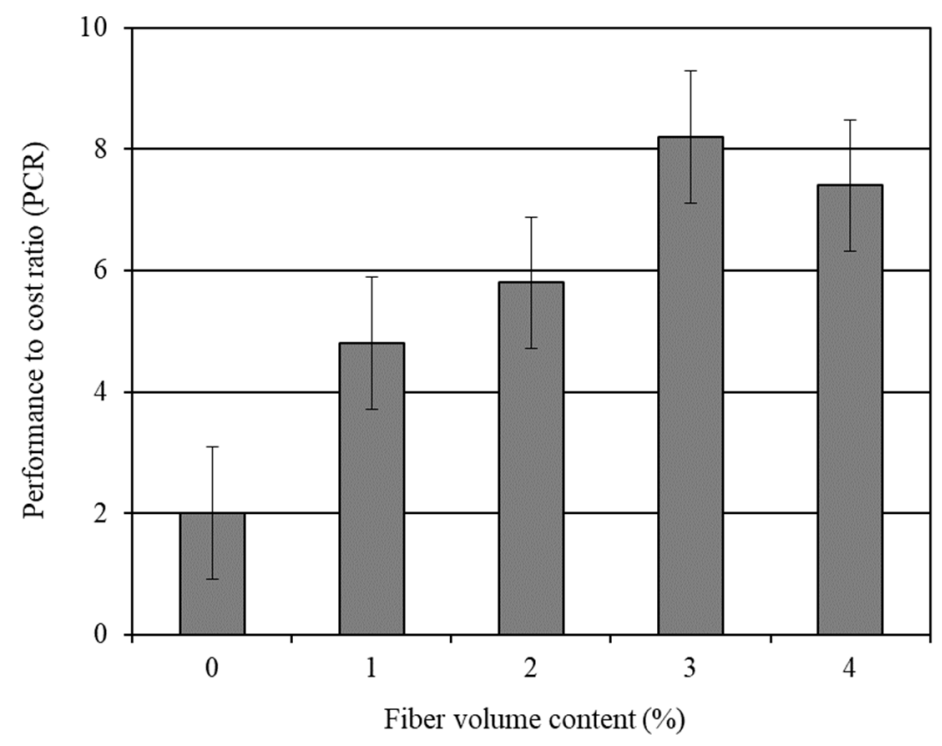

Figure 5. Influence of carbon fibers on the performance to cost ratio of mortar composite.

\section{Optimum Mortar Composite}

The optimum mortar composite was defined based on the overall performance regarding workability (flow time and volume flow), air content, unit weight, strength, and durability properties, as well as by considering the performance to cost ratios of various CFRMs. In general, the air content increased but the unit weight decreased when the carbon fibers were incorporated into the mortar composite. However, the increase in air content and the decrease in unit weight were the lowest for $3 \%$ carbon fibers. The inverted slump cone flow time, flexural strength, and impact resistance of CFRM composite increased, whereas its volume flow decreased with the higher volume content of the carbon fibers. Furthermore, the compressive strength increased for up to 3\% carbon fibers, and thereafter it dropped significantly. Conversely, the water absorption decreased for up to $3 \%$ carbon fibers, and then it increased substantially for $4 \%$ carbon fibers. The overall test results revealed that the mortar composite CFRM3, which included 3\% carbon fibers, possessed adequate workability for placing and compaction by vibration, maximum compressive strength, excellent flexural strength, and good impact resistance. Among all of the CFRMs, CFRM3 had the lowest air content and the highest unit weight. CFRM3 also exhibited the potential for good durability, as it had the lowest water absorption. Moreover, the highest performance to cost ratio was achieved for CFRM3. Hence, CFRM3 was the most costeffective mortar composite. In summary, CFRM3 can be considered as the optimum mortar composite from all perspectives.

\section{Conclusions}

- The flow time of the CFRM composite increased significantly with the increasing volume content of carbon fibers, which decreased the workability of mortar because the water demand to wet the constituent materials increased due to the large surface area of the fibers. Consequently, the volume flow of CFRM significantly decreased with the increased amount of carbon fibers.

- The unit weight of CFRM was lower than that of OPCM because of the increased air content and light weight of the carbon fibers. The CFRM mix with $3 \%$ carbon fibers possessed the highest unit weight among all of the CFRM mixes, because of its relatively low air content and high packing condition of constituent materials.

- The air content of CFRM was greater than that of OPCM because of the more entrapped air voids. However, CFRM3 with 3\% carbon fibers possessed the lowest air content among all of the CFRMs due to its adequate workability, which helped some of the air bubbles depart the mortar mix during vibration. 
- $\quad$ The compressive strength of CFRM increased with the inclusion of carbon fibers up to a $3 \%$ volume content when the fresh composite was sufficiently workable and well compacted. Such an improvement in compressive strength was attributed to the good interfacial bond of carbon fibers with the surrounding mortar matrix.

- The flexural strength of CFRM increased with the increasing carbon fiber content due to the greater resistance to crack propagation and the improved bond strength in the presence of silica fume.

- The impact resistance of CFRM increased extensively with the greater volume content of carbon fibers due to increased anchorage and the enhanced interfacial bond between the fibers and mortar matrix in the presence of silica fume.

- The incorporation of carbon fibers diminished the water absorption of CFRM when the mortar composite possessed sufficient workability and received good compaction.

- $\quad$ The PCR of CFRM was substantially higher than that of OPCM. This suggests that CFRM can be cost-effective, prevailing over the high material cost of carbon fibers. The highest PCR was obtained for the CFRM including 3\% carbon fibers.

- CFRM3 including 3\% carbon fibers can be considered as the optimum mortar composite, because it provided adequate workability, maximum compressive strength, relatively high unit weight and low air content, excellent flexural strength, good impact resistance, the lowest water absorption, and the highest performance to cost ratio.

Author Contributions: Conceptualization, M.S., G.A.-S. and N.H.; Data curation, M.S.; Formal analysis, M.S.; Investigation, M.S.; Methodology, M.S., G.A.-S. and N.H.; Project administration, G.A.-S. and N.H.; Resources, G.A.-S. and N.H.; Supervision, G.A.-S. and N.H.; Validation, M.S., G.A.-S. and N.H.; Visualization, M.S.; Writing—original draft, M.S.; Writing-review \& editing, M.S., G.A.-S. and N.H. All authors have read and agreed to the published version of the manuscript.

Funding: The authors acknowledge the financial support provided by the Ministry of Training, Colleges, and Universities of the Government of Ontario.

Institutional Review Board Statement: Not applicable.

Informed Consent Statement: Not applicable.

Data Availability Statement: The data underlying this article will be shared on reasonable request from the corresponding author.

Acknowledgments: The authors acknowledge sincere cooperation received from the Department of Civil and Environmental Engineering, University of Windsor, Windsor, Ontario, Canada. The authors are also thankful to Master Builders Technologies, Brampton, Ontario, Canada, for supplying silica fume and superplasticizer required for the experimental investigation.

Conflicts of Interest: The authors declare no conflict of interest.

\section{References}

1. Betterman, L.R.; Ouyang, C.; Shah, S.P. Fiber-mortar interaction in microfiber-reinforced mortar. Adv. Cem. Based Mater. 1995, 2, 53-61. [CrossRef]

2. Safiuddin, M.; Yakhlaf, M.; Soudki, K.A. Key mechanical properties and microstructure of carbon fibre reinforced selfconsolidating concrete. Construct. Build. Mater. 2018, 164, 477-488. [CrossRef]

3. Liao, W.-C.; Perceka, W.; Liu, E.-J. Compressive stress-strain relationship of high strength steel fiber reinforced concrete. J. Adv. Concr. Technol. 2015, 13, 379-392. [CrossRef]

4. ASTM C1116/C1116M-10a. Standard Specification for Fiber-Reinforced Concrete and Shotcrete; ASTM International: West Conshohocken, PA, USA, 2015.

5. ACI Committee 544. State-of-the-Art Report on Fiber Reinforced Concrete. In ACI Manual of Concrete Practice; Part 5; American Concrete Institute: Detroit, MI, USA, 1990.

6. Dinh, N.H.; Park, S.-H.; Choi, K.-K. Effect of dispersed micro-fibers on tensile behavior of uncoated carbon textile-reinforced cementitious mortar after high-temperature exposure. Cem. Concr. Compos. 2021, 118, 103949. [CrossRef]

7. Du, Q.; Cai, C.; Lv, J.; Wu, J.; Pan, T.; Zhou, J. Experimental investigation on the mechanical properties and microstructure of basalt fiber reinforced engineered cementitious composite. Materials 2020, 13, 3796. [CrossRef] [PubMed]

8. Graham, R.K.; Huang, B.; Shu, X.; Burdette, E.G. Laboratory evaluation of tensile strength and energy absorbing properties of cement mortar reinforced with micro- and meso-sized carbon fibers. Construct. Build. Mater. 2013, 44, 751-756. [CrossRef] 
9. Pierre, P.; Pleau, R.; Pigeon, M. Mechanical properties of steel microfiber reinforced pastes and mortars. J. Mater. Civ. Eng. 1999, 11, 317-324. [CrossRef]

10. Soroushian, P.; Khan, A.; Hsu, J.W. Mechanical properties of concrete materials reinforced with polypropylene or polyethylene fibers. ACI Mater. J. 1992, 89, 535-540.

11. Banthia, N.; Sheng, J. Strength and toughness of cement mortars reinforced with micro-fibers of carbon, steel, and polypropylene. In Proceedings of the Second Canadian Symposium on Cement and Concrete, University of British Columbia, Vancouver, BC, Canada, 24-26 July 1991; pp. 75-83.

12. Zhang, H.; Liu, Y.; Sun, H.; Wu, S. Transient dynamic behavior of polypropylene fiber reinforced mortar under dynamic loading. Construct. Build. Mater. 2016, 111, 30-42. [CrossRef]

13. George, M.; Sathyan, D.; Mini, K.M. Investigations on effect of different fibers on the properties of engineered cementitious composites. Mater. Today Proc. 2021, 42, 1417-1421. [CrossRef]

14. Deng, M.; Dong, Z.; Zhang, C. Experimental investigation on tensile behavior of carbon textile reinforced mortar (TRM) added with short polyvinyl alcohol (PVA) fibers. Construct. Build. Mater. 2020, 235, 117801. [CrossRef]

15. Toutanji, H.A.; El-Korchi, T.; Katz, R.N. Strength and reliability of carbon-fiber reinforced cement composites. Cem. Concr. Compos. 1994, 2, 15-21. [CrossRef]

16. Park, S.B.; Lee, B.I.; Lim, Y.S. Experimental study on the engineering properties of carbon fiber reinforced cement composites. Cem. Concr. Res. 1991, 21, 589-600. [CrossRef]

17. Mindess, S. Fibre reinforced concrete: Challenges and prospects. In Fiber Reinforced Concrete: Modern Developments; The University of British Columbia: Vancouver, BC, Canada, 1995; pp. 1-11.

18. Safiuddin, M.; Abdel-Sayed, G.; Hearn, H. High Performance Mortars with Short Carbon Fibers: Properties and Mix Optimization; Lambert Academic Publishing AG \& Co. KG: Saarbrücken, Germany, 2010.

19. Banthia, N. Pitch-based carbon fiber reinforced cements: Structure, performance, applications and research needs. Can. J. Civ. Eng. 1992, 19, 26-38. [CrossRef]

20. Akihama, S.; Suenaga, T.; Banno, T. Mechanical properties of carbon fiber reinforced cement composites. Int. J. Cem. Compos. Lightweight Concr. 1986, 8, 21-33. [CrossRef]

21. Akihama, S.; Suenaga, T.; Nakagawa, H. Carbon fiber reinforced concrete. Concr. Int. 1988, 10, 40-47. [CrossRef]

22. Safiuddin, M. High Performance Mortar Reinforced with Short Carbon Fibers. Master's Thesis, University of Windsor, Windsor, ON, Canada, 2003.

23. Banthia, N.; Sheng, J. Micro-reinforced cementitious materials. In Fiber-Reinforced Cementitious Materials, Proceedings of Materials Research Society; Materials Research Society: Philadelphia, PA, USA, 1990; Volume 211, pp. 25-32.

24. Banthia, N.; Dubeau, S. Carbon and steel micro-fiber reinforced cement-based composites for thin repairs. J. Mater. Civ. Eng. 1994, 6, 88-99. [CrossRef]

25. Banthia, N.; Genois, I. Pitch-based carbon fiber reinforced cement composites. In Fiber Reinforced Concrete: Modern Developments; The University of British Columbia: Vancouver, BC, Canada, 1995; pp. 213-228.

26. Banthia, N.; Azzabi, M.; Pigeon, M. Restrained shrinkage cracking in fiber reinforced cementitious composites. Mater. Struct. 1993, 26, 405-413. [CrossRef]

27. Banthia, N.; Moncef, A.; Chokri, K.; Sheng, J. Uniaxial tensile response of microfibre reinforced cement composites. Mater. Struct. 1995, 28, 507-517. [CrossRef]

28. Ohama, Y.; Amano, M. Effects of silica fume and water reducing agent on carbon fiber reinforced mortar. In Proceedings of the Japan Congress on Materials Research; The Society of Materials Science: Kyoto, Japan, 1984; Volume 27, pp. 187-191.

29. Ohama, Y.; Amano, M.; Endo, M. Properties of carbon fiber reinforced cement with silica fume. Concr. Int. 1985, 7, 58-62.

30. Morgan, D.R.; Razaqpur, A.G.; Crimi, J. Fibre reinforced concrete products. In Advanced Composite Materials in Bridges E Structures; Canadian Society for Civil Engineering: Montreal, QC, Canada, 1992; pp. 18-32.

31. Shah, S.P.; Rangan, B.V. Fiber reinforced concrete properties. Proc. ACI J. 1971, 68, 126-135.

32. Balaguru, P.N.; Narahari, R.; Patel, M. Flexural toughness of steel fiber reinforced concrete. ACI Mater. J. 1992, 89, 541-546.

33. Balaguru, P.N.; Shah, S.P. Fiber-Reinforced Cement Composites, International Edition; McGraw-Hill, Inc.: New York, NY, USA, 1992.

34. Zollo, R.F. Fiber-reinforced concrete: An overview after 30 years of development. Cem. Concr. Compos. 1997, 19, 107-122. [CrossRef]

35. Smarzewski, P. Influence of silica fume on mechanical and fracture properties of high performance concrete. Procedia Struct. Integr. 2019, 17, 5-12. [CrossRef]

36. Zhang, P.; Li, Q.-F. Effect of silica fume on fracture properties of high-performance concrete containing fly ash. Proc. Inst. Mech. Eng. Part L J. Mater. Des. Appl. 2012, 227, 336-342. [CrossRef]

37. ASTM C150/C150M-16. Standard Specification for Portland Cement; ASTM International: West Conshohocken, PA, USA, 2016.

38. ASTM C1240-15. Standard Specification for Silica Fume Used in Cementitious Mixtures; ASTM International: West Conshohocken, PA, USA, 2015.

39. ASTM C94/C94M-16. Standard Specification for Ready-Mixed Concrete; ASTM International: West Conshohocken, PA, USA, 2016.

40. ASTM C494/C494M-16. Standard Specification for Chemical Admixtures for Concrete; ASTM International: West Conshohocken, PA, USA, 2016. 
41. Johnston, C.D. Fiber reinforced concrete. In Proceedings of the CANMET/ACI International Conference on Advances in Concrete Technology, Athens, Greece, 11-15 May 1992; pp. 629-697.

42. Safiuddin, M.; Abdel-Sayed, G.; Hearn, N. Effects of pitch-based short carbon fibers on the workability, unit weight, and air content of mortar composite. Fibers 2018, 6, 63. [CrossRef]

43. ASTM C172/C172M-14. Standard Practice for Sampling Freshly Mixed Concrete; ASTM International: West Conshohocken, PA, USA, 2014.

44. ASTM C995-01. Standard Test Method for Time of Flow of Fiber-Reinforced Concrete through Inverted Slump Cone; ASTM International: West Conshohocken, PA, USA, 2002.

45. ASTM C138/C138M-16. Standard Test Method for Density (Unit Weight), Yield, and Air Content (Gravimetric) of Concrete; ASTM International: West Conshohocken, PA, USA, 2016.

46. ASTM C192/C192M-14. Standard Practice for Making and Curing Concrete Test Specimens in the Laboratory; ASTM International: West Conshohocken, PA, USA, 2014.

47. ASTM C39/C39M-16. Standard Test Method for Compressive Strength of Cylindrical Concrete Specimens; ASTM International: West Conshohocken, PA, USA, 2016.

48. ASTM C617/C617M-15. Standard Practice for Capping Cylindrical Concrete Specimens; ASTM International: West Conshohocken, PA, USA, 2015.

49. ASTM C1018-97. Standard Test Method for Flexural Toughness and First-Crack Strength of Fiber-Reinforced Concrete (Using Beam with Third-Point Loading); ASTM International: West Conshohocken, PA, USA, 1998.

50. ACI Committee 544. Measurement of properties of fiber reinforced concrete. ACI Mater. J. 1988, 85, 583-593.

51. ASTM D1557-12e1. Test Methods for Laboratory Compaction Characteristics of Soil Using Modified Effort $\left(56,000 \mathrm{ft}-\mathrm{lb} / \mathrm{ft} 3\left(2700 \mathrm{kN}-\mathrm{m} / \mathrm{m}^{3}\right)\right)$; ASTM International: West Conshohocken, PA, USA, 2012.

52. ASTM C1195-03. Standard Test Method for Absorption of Architectural Cast Stone; ASTM International: West Conshohocken, PA, USA, 2003.

53. Nehdi, M.; Mindess, S.; Aïtcin, P.-C. Optimization of high strength limestone filler cement mortars. Cem. Concr. Res. 1996, 26, 883-893. [CrossRef]

54. Bayasi, M.Z.; Soroushian, J. Effect of steel fiber reinforcement on fresh mix properties of concrete. ACI Mater. J. 1992, 89, 369-374.

55. Banthia, N.; Moncef, A.; Sheng, J. Uni-axial tensile response of cement composites reinforced with high volume fractions of carbon, steel and polypropylene micro-fibers. In Thin Reinforced Concrete Products and Systems, ACI SP-146; American Concrete Institute: Detroit, MI, USA, 1994; pp. 43-68.

56. Safiuddin, M.; George Abdel-Sayed, G.; Hearn, N. Absorption and strength properties of short carbon fiber reinforced mortar composite. Buildings 2021, 11, 300. [CrossRef]

57. Donnini, J.; Bellezze, T.; Corinaldesi, V. Mechanical, electrical and self-sensing properties of cementitious mortars containing short carbon fibers. J. Build. Eng. 2018, 20, 8-14. [CrossRef]

58. Vipulanandan, C.; Garas, V. Electrical resistivity, pulse velocity, and compressive properties of carbon fiber-reinforced cement mortar. J. Mater. Civ. Eng. 2008, 20, 93-101. [CrossRef]

59. Li, Y.-F.; Lee, K.-F.; Ramanathan, G.K.; Cheng, T.-W.; Huang, C.-H.; Tsai, Y.-K. Static and dynamic performances of chopped carbon-fiber-reinforced mortar and concrete incorporated with disparate lengths. Materials 2021, 14, 972. [CrossRef] [PubMed]

60. Zhang, X.; Ge, L.; Zhang, Y.; Wang, J. Mechanical properties of carbon-fiber RPC and design method of carbon-fiber content under different curing systems. Materials 2019, 12, 3759. [CrossRef]

61. Liu, D.J.; Chen, M.J.; Xue, L.; He, F.; Hu, J. The effect of the carbon fiber on concrete compressive strength. Adv. Mater. Res. 2018, 1145, 106-111. [CrossRef]

62. Ali, B.; Raza, S.S.; Hussain, I.; Iqbal, M. Influence of different fibers on mechanical and durability performance of concrete with silica fume. Struct. Concr. 2021, 22, 318-333. [CrossRef]

63. Katz, A.; Li, V.C.; Kazmer, A. Bond properties of carbon fibers in cementitious matrix. J. Mater. Civ. Eng. 1995, 7, 125-128. [CrossRef]

64. Pigeon, M.; Pleau, R.; Azzabi, M.; Banthia, N. Durability of microfiber reinforced mortars. Cem. Concr. Res. 1996, 26, 601-609. [CrossRef]

65. Kim, T.-J.; Park, C.-K. Flexural and tensile strength developments of various shape carbon fiber-reinforced lightweight cementitious composites. Cem. Concr. Res. 1998, 28, 955-960. [CrossRef]

66. Sakai, H.; Takahashi, K.; Mitsui, Y.; Ando, T.; Awata, M.; Hoshijima, T. Flexural behavior of carbon fiber reinforced cement composite. In Fiber Reinforced Concrete: Developments and Innovations; ACI SP-142; American Concrete Institute: Detroit, MI, USA, 1994; pp. 73-89.

67. Safiuddin, M.; Jumaat, M.Z.; Salam, M.A.; Rahman, M.A. Effects of palm oil fuel ash on the permeable porosity and water absorption of high-strength concrete. In Proceedings of the First Australasia and South-East Asia Structural Engineering and Construction Conference, Perth, Australia, 28 November-2 December 2012; pp. 457-462.

68. Tavares, L.R.C.; Junior, J.F.T.; Costa, L.M.; Bezerra, A.C.D.S.; Cetlin, P.R.; Aguilar, M.T.P. Influence of quartz powder and silica fume on the performance of Portland cement. Sci. Rep. 2020, 10, 21461. [CrossRef] [PubMed]

69. Song, H.W.; Park, S.W.; Nam, S.H.; Jang, J.C.; Sarawathy, V. Estimation of the permeability of silica fume cement concrete. Construct. Build. Mater. 2010, 24, 315-321. [CrossRef] 
70. Cheng-Yi, H.; Feldman, R.F. Influence of silica fume on the micro-structural development in cement mortars. Cem. Concr. Res. 1985, 15, 285-294. [CrossRef]

71. Ivanič, A.; Lubej, S.; Rudolf, R.; Anžel, I. Bond behavior of carbon-fi ber yarn embedded in cement mortar. Sci. Eng. Compos. Mater. 2011, 18, 181-186. [CrossRef] 